\title{
Breast cancer mortality trends in Peruvian women
}

\author{
J. Smith Torres-Roman ${ }^{1,2,3^{*}}$ (D), Jose Fabian Martinez-Herrera ${ }^{3,4}$, Greta Carioli, Jorge Ybaseta-Medina ${ }^{6}$, \\ Bryan Valcarcel ${ }^{3}$, Joseph A. Pinto ${ }^{7}$, Alfredo Aguilar ${ }^{7}$, Katherine A. McGlynn $^{8}$ and Carlo La Vecchia ${ }^{5}$
}

\begin{abstract}
Background: Breast cancer (BC) is the most common malignancy in Latin American women, but with a wide variability with respect to their mortality. This study aims to estimate the mortality rates from $B C$ in Peruvian women and to assess mortality trends over 15 years.

Methods: We calculated BC age-standardized mortality rate (ASMR) per 100,000 women-years using the world standard SEGI population. We estimated joinpoint regression models for BC in Peru and its geographical areas. The spatial analysis was performed using the Moran's I statistic.

Results: In a 15-year period, Peru had a mortality rate of 9.97 per 100,000 women-years. The coastal region had the highest mortality rate (12.15 per 100,000 women-years), followed by the highlands region (4.71 per 100,000 womenyears). In 2003, the highest ASMR for BC were in the provinces of Lima, Arequipa, and La Libertad (above 8.0 per 100, 000 women-years), whereas in 2017, the highest ASMR were in Tumbes, Callao, and Moquegua (above 13.0 per women-years). The mortality trend for BC has been declining in the coastal region since 2005 (APC $=-1.35, p<0.05$ ), whereas the highlands region experienced an upward trend throughout the study period $(A P C=4.26, p<0.05)$. The rainforest region had a stable trend. Spatial analysis showed a Local Indicator of Spatial Association of $0.26(p<0.05)$.

Conclusion: We found regional differences in the mortality trends over 15 years. Although the coastal region experienced a downward trend, the highlands had an upward mortality trend in the entire study period. It is necessary to implement tailored public health interventions to reduce BC mortality in Peru.
\end{abstract}

Keywords: Breast cancer, Geographic spatial analysis, Mortality rate, Epidemiology, Female, Peru

\section{Background}

Breast cancer is the most common malignancy and the leading cause of cancer-related death among women worldwide [1]. In 2018, GLOBOCAN estimated 2.1 million breast cancer cases in women, accounting for almost $25 \%$ of all cancers [1]. Compared to high-income countries, breast cancer survival rates are lower in low- and middle-

\footnotetext{
* Correspondence: jstorresroman@gmail.com

${ }^{1}$ Universidad Cientifica del Sur, Lima, Peru

${ }^{2}$ Instituto de Investigación, Universidad Católica Los Ángeles de Chimbote, Chimbote, Peru

Full list of author information is available at the end of the article
}

income countries (LMICs) [2], due to late diagnosis and inadequate access to cancer care [2,3].

In the last years, breast cancer mortality has experienced downward trends in all Latin American countries (except Cuba); however, breast cancer continues to be one of the neoplasms with the highest mortality in Latin America [4-6]. Between 1980 and 2010, the highest mortality rates were in Argentina and Uruguay (around 20 deaths per 100,000 women-years), whereas the lowest rates were in Colombia, Mexico, and Ecuador (around 10 per 100,000 women-years) [4].

According to the GLOBOCAN 2018, breast cancer is the third cause of cancer death in Peruvian women, with

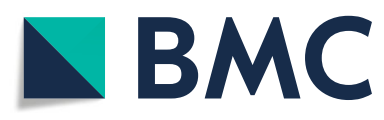

(c) The Author(s). 2020 Open Access This article is licensed under a Creative Commons Attribution 4.0 International License, which permits use, sharing, adaptation, distribution and reproduction in any medium or format, as long as you give appropriate credit to the original author(s) and the source, provide a link to the Creative Commons licence, and indicate if changes were made. The images or other third party material in this article are included in the article's Creative Commons licence, unless indicated otherwise in a credit line to the material. If material is not included in the article's Creative Commons licence and your intended use is not permitted by statutory regulation or exceeds the permitted use, you will need to obtain permission directly from the copyright holder. To view a copy of this licence, visit http://creativecommons.org/licenses/by/4.0/. The Creative Commons Public Domain Dedication waiver (http://creativecommons.org/publicdomain/zero/1.0/) applies to the data made available in this article, unless otherwise stated in a credit line to the data. 
an age-standardized mortality rate (ASMR) of 10.3 per 100,000 women [1], mainly affecting women in the coastal region [6]. However, there are no epidemiological studies on breast cancer mortality rates and trends from Peru and its geographical areas in the last years. This study aimed to estimate mortality rates from breast cancer among Peruvian women by geographical areas and to assess trends over time in Peru and its regions.

\section{Methods}

\section{Design and study setting}

We retrieved mortality data from the registry of deaths of the Peru Ministry of Health (MINSA, in Spanish) from the period 2003-2017: https://www.minsa.gob.pe/portada/ transparencia/solicitud/. MINSA collects mortality data at the national level using different sources: 1 ) all health establishment records, 2) the Registro Nacional de Identificación y Estado Civil, and 3) the Public Ministry [7]. These data cover the number of deaths for each disease aggregated by gender into 5 age groups $(0-11,12-17,18-29,30-59$, and $\geq 60)$ as in similar studies in Peru $[7,8]$. We aggregated the 3 first age group in the young $(0-29$ years) group and calculated the age-adjusted mortality rates for the groups
$0-29,30-59$, and $\geq 60$. We used the code C50 to identify deaths from breast cancer, according to the International Classification of Diseases, 10th Revision [9]. Population denominators were obtained from census data in 2005, 2010, and 2015, conducted by the National Institute of Statistics and Informatics, which is the central and governing body of the National Statistical System, responsible he country's official statistics [10].

Peru has 25 provinces located in three natural regions delimitated by the Andes mountains: coast, highlands, and rainforest [11]. The coast is the most densely populated region $(56.3 \%$ of the total population) and represents the $11.7 \%$ of the territory [12]. The highlands, covering $27.9 \%$ of the national territory and $29.7 \%$ of the population [11], is a rural and urban high-altitude area throughout the Andes [12]. The rainforest, or the Peruvian Amazon, constitutes $60.3 \%$ of the territory, where $14.0 \%$ of the total population lives (Fig. 1).

\section{Ethical considerations}

This manuscript is based on population databases and does not use any personal identifiable information. To

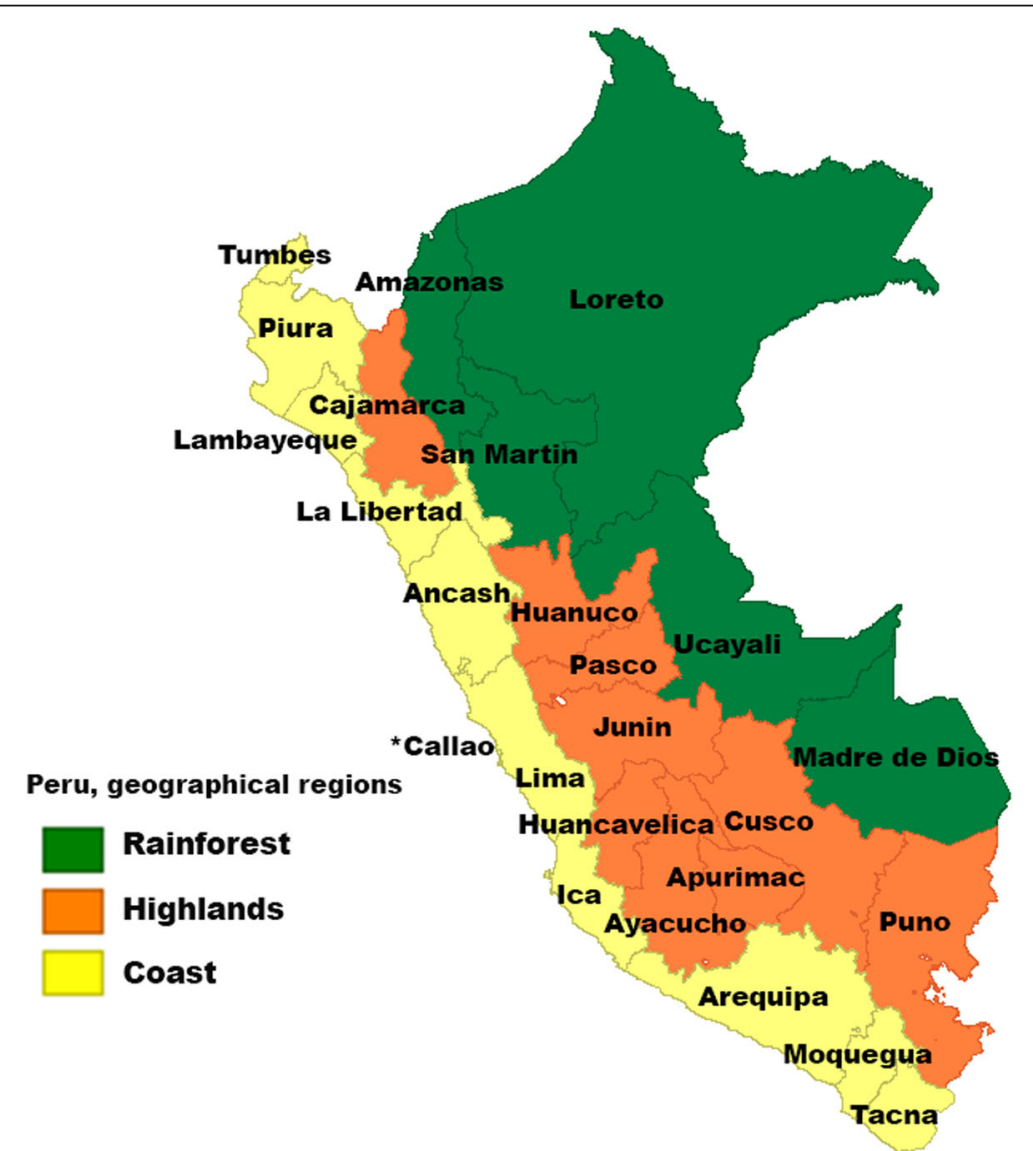

Fig. 1 Peru geographical areas by provinces and regions. The asterisk denotes Callao province. Map created through GEODA version 1.14.0. Available in: https://geodacenter.github.io/index.html 
obtain the raw data it was only necessary to fill out a form with the applicant's data through:

https://www.minsa.gob.pe/portada/transparencia/solicitud/.

\section{Correction of under-reporting}

Peru reported a rate of omission regarding the notification of the cause of death of 46\%, ranging between 19\% (province of Ica) and 78\% (province of Loreto) [13]. The variable degree of coverage in the register of deaths from one province to another was corrected from 2003 to 2017 to be the known underreporting rate for each province, as a previous study [8]:
$\mathrm{R}=100-(\mathrm{OD} / \mathrm{ED}) \times 100$.

$\mathrm{R}=$ Underreporting rate.

$\mathrm{OD}=$ number of deaths observed for each province.

$\mathrm{ED}=$ number of deaths estimated for each province.

\section{Data analysis}

With information on the number of deaths, corrected for the underreporting rate, we calculated age-standardized mortality rates per 100,000 women-years using the world standard SEGI population [14]. We analyzed mortality trends using the joinpoint regression program, version 4.7.0 $[15,16]$. This model identified significant changes in

Table 1 Breast cancer deaths and mortality rates in Peru and its geographical areas from 2003 to 2017

\begin{tabular}{|c|c|c|c|c|}
\hline \multirow{2}{*}{$\begin{array}{l}\text { Geographical } \\
\text { areas }\end{array}$} & \multicolumn{2}{|l|}{ Deaths $^{a}$} & \multicolumn{2}{|c|}{ Mortality rates $^{\mathbf{b}}$} \\
\hline & Uncorrected & Corrected & Uncorrected & Corrected \\
\hline Peru & 13,059 & 20,541 & 6.30 & 9.97 \\
\hline \multicolumn{5}{|l|}{ Regions } \\
\hline Coast & 11,466 & 16,905 & 8.21 & 12.15 \\
\hline Highlands & 1229 & 2498 & 2.33 & 4.71 \\
\hline Rainforest & 364 & 1138 & 2.48 & 7.94 \\
\hline \multicolumn{5}{|l|}{ Provinces } \\
\hline Amazonas & 66 & 253 & 2.80 & 10.91 \\
\hline Ancash & 215 & 455 & 2.66 & 5.67 \\
\hline Apurimac & 33 & 80 & 1.13 & 2.74 \\
\hline Arequipa & 649 & 932 & 6.96 & 10.06 \\
\hline Ayacucho & 56 & 139 & 1.39 & 3.45 \\
\hline Cajamarca & 219 & 551 & 2.22 & 5.57 \\
\hline Callao & 720 & 915 & 9.87 & 12.64 \\
\hline Cusco & 173 & 372 & 2.01 & 4.27 \\
\hline Huancavelica & 30 & 62 & 1.14 & 2.40 \\
\hline Huanuco & 154 & 301 & 3.02 & 5.87 \\
\hline Ica & 484 & 559 & 8.73 & 10.10 \\
\hline Junin & 320 & 552 & 3.71 & 6.40 \\
\hline La Libertad & 950 & 1365 & 7.57 & 10.99 \\
\hline Lambayeque & 812 & 1030 & 8.97 & 11.46 \\
\hline Lima & 6518 & 9896 & 9.08 & 13.83 \\
\hline Loreto & 85 & 386 & 1.83 & 8.32 \\
\hline Madre de Dios & 23 & 31 & 3.67 & 5.13 \\
\hline Moquegua & 72 & 107 & 6.09 & 9.06 \\
\hline Pasco & 49 & 104 & 2.77 & 5.93 \\
\hline Piura & 840 & 1310 & 7.12 & 11.18 \\
\hline Puno & 195 & 336 & 2.11 & 3.61 \\
\hline San Martin & 119 & 326 & 2.75 & 7.56 \\
\hline Tacna & 123 & 184 & 6.52 & 9.75 \\
\hline Tumbes & 83 & 146 & 7.09 & 12.19 \\
\hline Ucayali & 71 & 142 & 2.69 & 5.30 \\
\hline
\end{tabular}

${ }^{a}$ Cumulative deaths for a 15-year period (2003-2017)

${ }^{\mathrm{b}}$ Age-standardized rates per 100,000 women-years 
trends, to identify the occurrence of possible joinpoints, allowing a minimum of zero joinpoints and a maximum of three joinpoints. For each time trend identified by the model, we estimated the annual percentage change (APC) [16]. We considered APCs statistically significant at a $p$ value $<0.05$. For the provinces with more than 2 joinpoints, the average annual percentage changes (AAPC) were calculated. The significance levels utilized are based on the Monte Carlo permutation model and the calculation of the annual percentage change of ratio, utilizing the logarithm of the ratio $[16,17]$.

The GeoDA software was used to assess the spatial distribution [18]. The spatial analysis was performed using the Moran's I statistic and the Local Indicator of Spatial Association (LISA), which assess whether mortality rates are clustered, dispersed, or random. The spatial representation was made using Moran's local index known as LISA, this spatial typology consisted of five categories of health regions: (i) clusters with high breast cancer mortality rates surrounded by provinces with higher than average rates ('high-high'); (ii) clusters with low breast cancer mortality rates surrounded by provinces with higher than average rates ('lowhigh'); (iii) clusters with low breast cancer mortality rates surrounded by provinces with lower than average rates ('low-low') (positive autocorrelation); (iv) clusters with high breast cancer mortality rates surrounded by provinces with lower than average rates ('high-low')]; and (v) 'not significant'. Values of Moran's I range approximately from 1 (positive spatial autocorrelation, perfect grouping of similar rates) to 1 (negative spatial autocorrelation, spatial dispersion). We used a reference distribution using 999 random permutations to indicate statistical significance.

\section{Results}

In the 2003-2017 period, we estimated 20,541 cumulative deaths from breast cancer in Peruvian women. The average mortality rate (per 100,000 women-years) over 15 years was of 9.97, in Peru. According to its regions, the coastal region had the highest rate (12.15), followed by the highlands (4.71), and the rainforest (7.94) regions. The provinces with the highest mortality rates in the overall period were Lima, Callao, and Tumbes, while the lowest rates were in Apurimac and Huancavelica (Table 1).

Figure 2 shows age-standardised mortality rates (ASMRs) for breast cancer from 2003 to 2017 in Peru and its 25 provinces. The ASMRs only declined in three provinces,

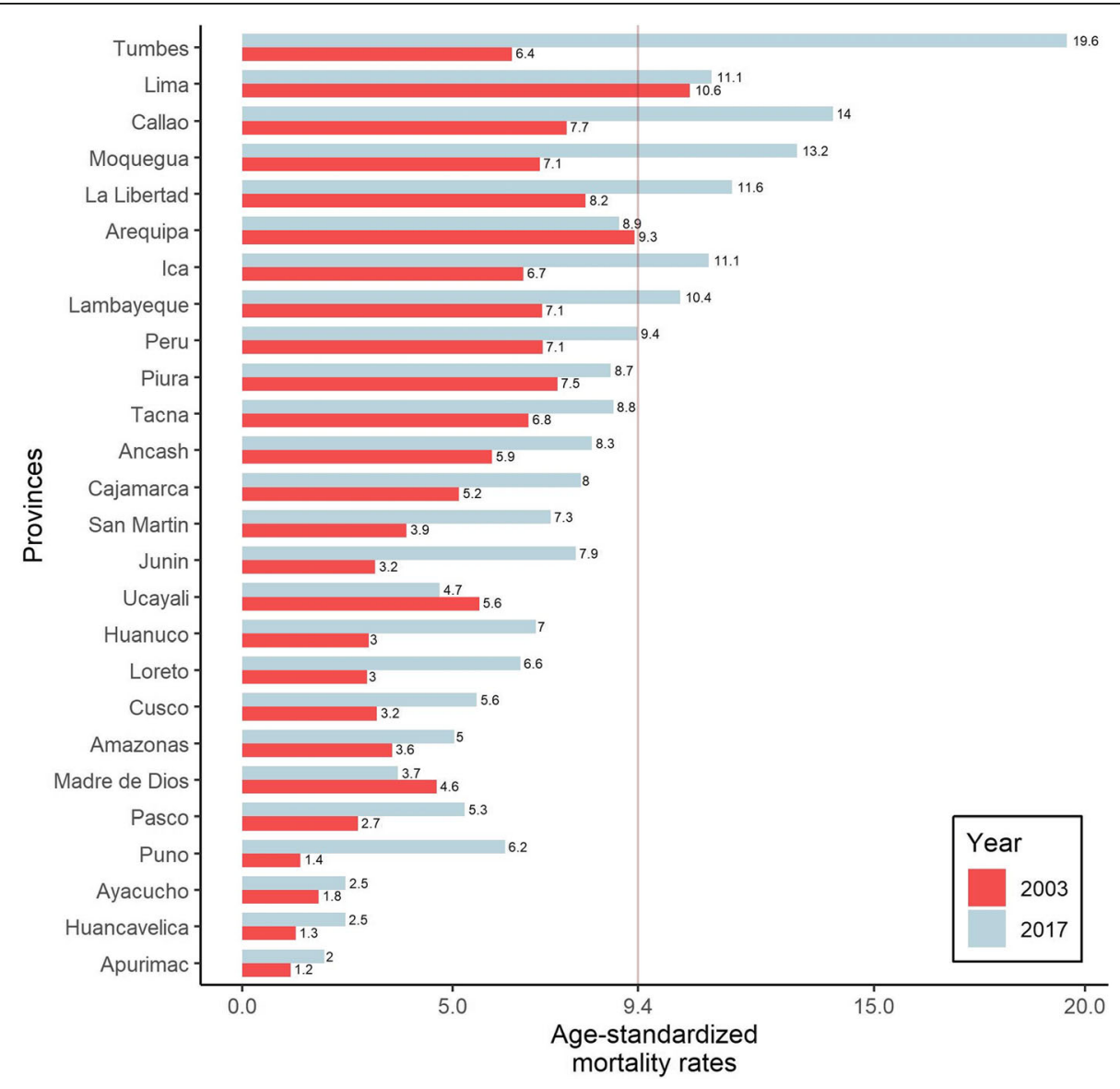

Fig. 2 Age-standardised mortality rates (ASMRs) for breast cancer in 2003 and 2017 
Arequipa (from 9.3 to 8.9), Ucayali (from 5.6 to 4.7), and Madre de Dios (from 4.6 to 3.7). Seven coastal provinces (Tumbes, Lima, Callao, Moquegua, La Libertad, Ica, and Lambayeque) had higher mortality rates compared to the average rate of Peru in 2017 (dashed line in Fig. 2).

Figure 3 shows the mortality trends for Peru and its regions between 2003 and 2017. The joinpoint analysis identified an initial upward trend in Peru $(\mathrm{APC}=19)$ between 2003 and 2005, followed by a downward trend since 2005 until $2017(\mathrm{APC}=-0.5)$. Similarly, the coastal region showed an annual increase of $20.2 \%$ from 2003 to 2005, and then start to significantly decrease until 2017 (ACP =
$-1.35, p<0.05)$. In contrast, both the highlands $(\mathrm{APC}=$ 4.26, $\mathrm{p}<0.05)$ and rainforest $(\mathrm{APC}=1.62)$ regions had a steady mortality increase over the study period.

Table 2 displays the age-standardized mortality rates for breast cancer per 100,000 women-years in the Peruvian provinces and its AAPC, between 2003 and 2017. The highest rise were in Puno (from 1.39 in 2003 to 6.24 in 2017, $\mathrm{AAPC}=6.2,95 \% \mathrm{CI}: 3.0$ to $9.6 \%$ ), Tumbes (from 6.41 in 2003 to 19.58 in 2017, $\mathrm{AAPC}=1.3,95 \% \mathrm{CI}:-7.5$ to $11.0 \%$ ), and Junin (from 3.16 in 2003 to 7.92 in 2017, AAPC =6.7, 95\%CI: 3.4 to $10.2 \%)$. Moreover, Ancash and Apurimac provinces also showed upward mortality trends. Ancash had an increase from 5.93 to 8.31 (AAPC $=+4.1,95 \% \mathrm{CI}$ :
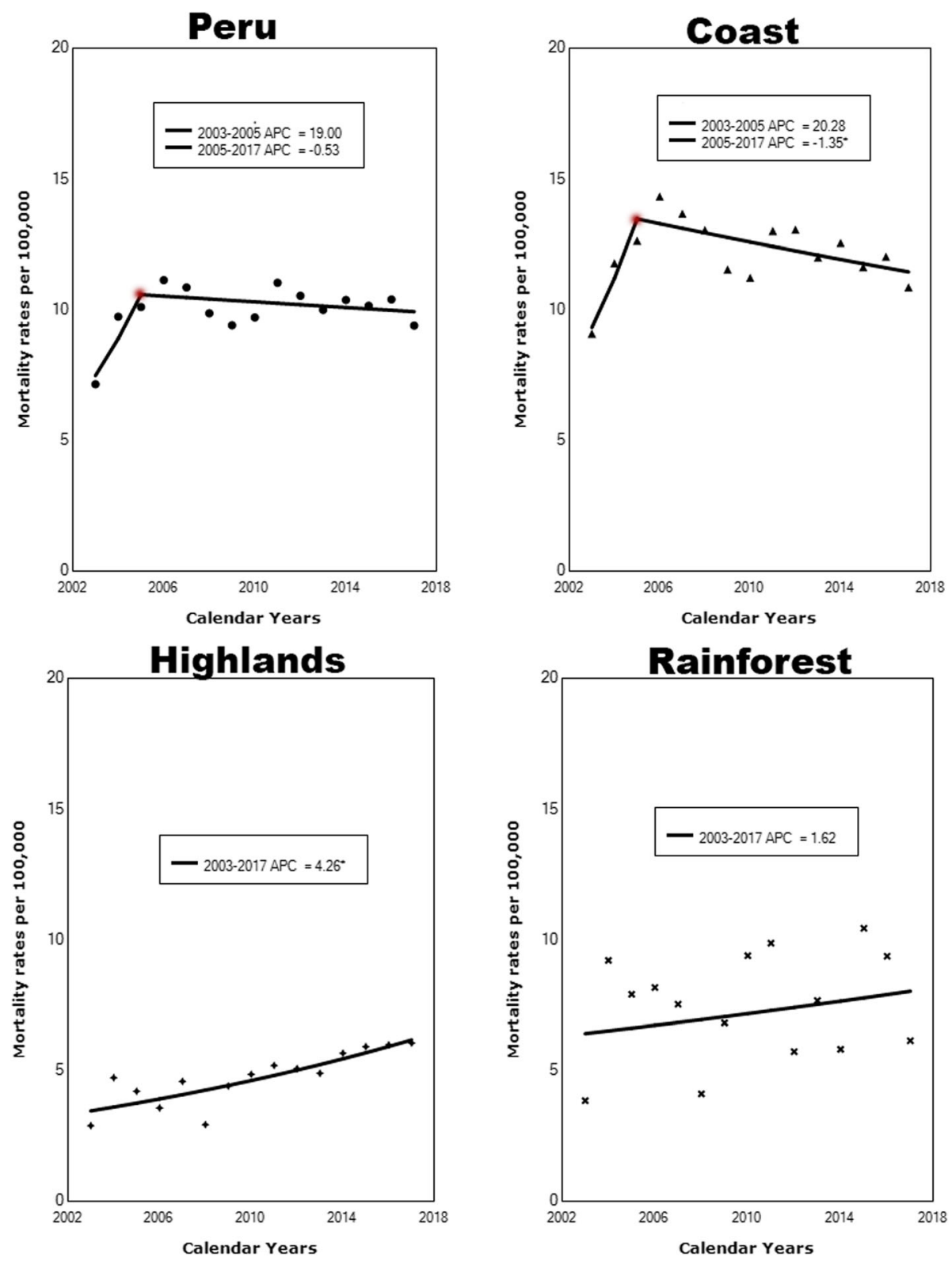

Fig. 3 Joinpoint analysis for breast cancer in Peru and its regions between 2003 and 2017 
Table 2 Age-standardized (world population) mortality rates per 100,000 women from breast cancer in Peruvian provinces, 2003 and 2017, corresponding percent changes (2017 vs 2003), and its Average Annual Percentage Changes

\begin{tabular}{|c|c|c|c|c|}
\hline Provinces & 2003 & 2017 & \%change $2003 / 2017$ & AAPC $(95 \% \mathrm{Cl})$ \\
\hline Amazonas & 3.56 & 5.04 & 41.51 & $2.4(-6.5,12.1)$ \\
\hline Ancash & 5.93 & 8.31 & 39.99 & $4.1(0.7,7.5)$ \\
\hline Apurimac & 1.15 & 1.96 & 70.16 & $9.2(1.6,17.2)$ \\
\hline Arequipa & 9.32 & 8.95 & -4.03 & $-0.8(-2.8,1.2)$ \\
\hline Ayacucho & 1.82 & 2.46 & 35.11 & $2.9(-2.4,8.4)$ \\
\hline Cajamarca & 5.15 & 8.04 & 55.99 & $3.3(-0.2,6.8)$ \\
\hline Callao & 7.70 & 14.03 & 82.24 & $4.2(-2.2,11.1)$ \\
\hline Cusco & 3.20 & 5.57 & 73.89 & $1.3(-3.1,6.0)$ \\
\hline Huancavelica & 1.27 & 2.45 & 92.30 & $-1.3(-9.5,7.7)$ \\
\hline Huanuco & 3.01 & 6.98 & 132.05 & $2.1(-3.2,7.3)$ \\
\hline Ica & 6.68 & 11.07 & 65.83 & $2.7(-1.0,6.4)$ \\
\hline Junin & 3.16 & 7.92 & 150.61 & $6.7(3.4,10.2)$ \\
\hline La Libertad & 8.15 & 11.63 & 42.71 & $1.3(-0.4,3.1)$ \\
\hline Lambayeque & 7.12 & 10.40 & 46.13 & $-0.1(-3.1,3.0)$ \\
\hline Lima & 10.62 & 11.14 & 4.86 & $0.7(-1.9,3.4)$ \\
\hline Loreto & 2.97 & 6.61 & 122.46 & $2.5(-6.9,12.8)$ \\
\hline Madre de Dios & 4.62 & 3.70 & -19.81 & $0.3(-8.4,9.8)$ \\
\hline Moquegua & 7.07 & 13.17 & 86.32 & $0.4(-7.7,9.2)$ \\
\hline Pasco & 2.75 & 5.29 & 92.46 & $2.3(-6.4,11.9)$ \\
\hline Piura & 7.48 & 8.75 & 16.93 & $1.4(-0.8,3.6)$ \\
\hline Puno & 1.39 & 6.24 & 348.99 & $6.2(3.0,9.6)$ \\
\hline San Martin & 3.91 & 7.32 & 87.43 & $3.3(-1.7,8.6)$ \\
\hline Tacna & 6.80 & 8.81 & 29.55 & $-1.4(-5.4,2.8)$ \\
\hline Tumbes & 6.41 & 19.58 & 205.32 & $1.3(-7.5,11.0)$ \\
\hline Ucayali & 5.63 & 4.69 & -16.65 & $-3.3(-7.8,1.5)$ \\
\hline
\end{tabular}

AAPC Average Annual Percent Change

$0.7,7.5)$; Apurimac increased from 1.15 to $1.96(\mathrm{AAPC}=+$ 9.2, 95\% CI: 1.6, 17.2).

Figure 4 shows significant clustering and spatial outliers in the map according to the breast cancer mortality rates. A statistically significant cluster for "High-High" (red) occurrence was detected in Callao province, while "LowLow" (blue) were identified in 3 provinces (Madre de Dios, Cusco, and Ayacucho), which had low rates, also surrounded by provinces with lower than average rates. Spatial analysis showed a LISA for provinces breast cancer mortality rates of $0.26(p<0.05)$.

\section{Discussion}

We report the mortality rates of breast cancer over 15 years, with their trends using joinpoint regression models, and spatial analysis for Peru and its geographical areas. Our study showed stable trend in breast cancer mortality in Peru over the last two decades, but with differences across its regions. The coastal region showed the highest mortality rates in the analysed period, whereas the highlands region, despite having the lowest rates, experienced an upward trend.

The mortality rates increased during the first years of the study, probably due to an improvement in diagnosis and certification of deaths in various provinces of Peru [19]. In addition, in some provinces, the rates were so low that they likely represent underreporting of mortality. However, it is plausible that data quality has increased in last years [19].

Our findings differed from other areas of the world (most countries from Western Europe, North America, or some other Latin American countries) [5, 6, 20]. A study on breast cancer mortality trends and predictions for 2020 in the Americas and Australasia, including 7 Latin American countries [20], reported between 2000 and 2004, the highest mortality rates (per 100,000 women-years) in Argentina (19.75) and Uruguay (21.6), whereas Colombia (9.68) and Mexico (9.03) had the lowest mortality rates, with stables rates, and further expected $10 \%$ reduction in the overall rates for 2020. Peru is, therefore, among the countries with the lowest rates in the region.

Several factors influence the variations in breast cancer death certification across Latin American countries. These factors include a high burden of locally advanced/advanced breast cancer, inadequate access to healthcare resources, deficient access to specialized cancer care, and insufficient research [21]. Peru has a fragmented healthcare system with five major providers that have independent system structures and offer healthcare through different plans. Furthermore, approximately $25 \%$ of the population is uninsured [22] and lacks access to early diagnosis [23]. For instance, mammography has been reported more frequently among women with higher educational status, greater economic income, and living in major urban cities of the country with easier access to healthcare [24]. A persistent problem in Peru is the diagnosis at a late stage in one-third of breast cancer cases. Justo et al. reported that $32-33 \%$ of the patients had stage III at diagnosis, while $7-16 \%$ had stage IV [3]. These factors probably affect breast cancer case fatality, but without information on the incidence, it is difficult to assess the impact of these factors on mortality.

The coastal region had the highest mortality rates for breast cancer, principally in the Lima and Callao provinces, but over recent years showed downward trends. This region has the lowest poverty rates compared to the highlands or the rainforest [25] and the highest proportion of the oncological workforce (72\% of clinical oncologists and $85 \%$ of radio-oncologists) [26]. Therefore, the population living on the coast has higher access to healthcare and better cancer detection, positively affecting mortality.

There are other possible explanations for the difference in mortality rates in the coastal region, such as 

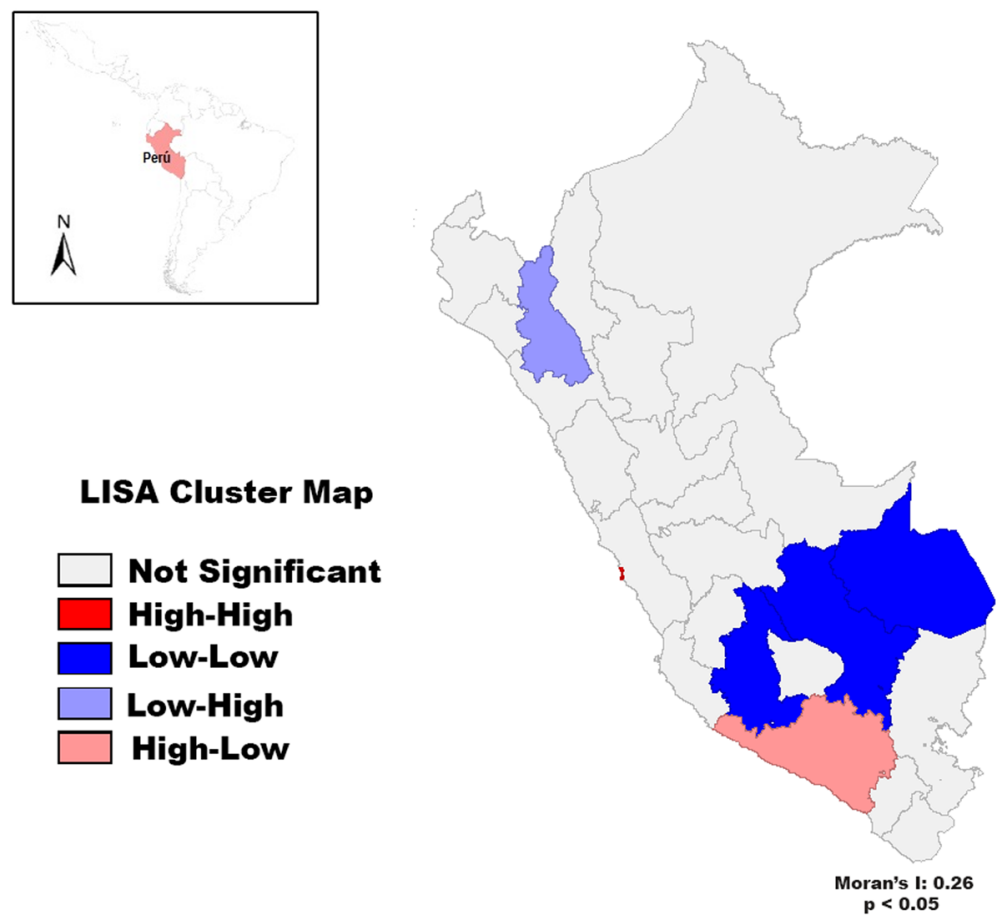

Fig. 4 Cluster map for breast cancer in Peruvian women between 2003 and 2017. Map created through GEODA version 1.14.0. Available in: https://geodacenter.github.io/index.html

racial differences [27], a higher percentage of obesity [28], higher alcohol consumption [29], and genetic susceptibility [30, 31]. In fact, the coastal region has the highest proportion of black women [32], mainly in the North and Centre. Also, several studies have reported a high prevalence of triple-negative breast cancer (TNBC) in Peruvian women [33,34], with most cases identified in the coastal region [34]. Moreover, the women of the rainforest region were more likely to be diagnosed with TNBC compared to women of the highland region ( $31 \%$ vs. $14 \%$ ), where the risk of mortality was 1.7 times higher in women of the rainforest [35]. It has been suggested that the distribution of breast cancer subtypes is due to the proportion of indigenous women in the two regions of Peru [35].

The Peruvian government made serious efforts to improve early detection, diagnosis, and treatment for cancer in the early 2010s. The Plan Esperanza aimed to decentralise healthcare to all the provinces, improve cancer screening, and provide treatment at a lower cost [36]. This practice tends to increase the diagnosis of cancer, because of better detection, which consequently increases the mortality rates. Hence, the higher mortality rate in the period 2013-2017 may reflect the effect of the Plan Esperanza, especially in the highland provinces. However, it is still too soon to observe a benefit from this nationwide program on mortality reduction. Other efforts have begun to establish an effective model in low resource areas, such as training health promoters for community outreach, training professionals to perform fine-needle aspiration biopsy sampling, and ensuring that patients adhere to treatment regimens [37]. These strategies will become part of the national strategy to reduce mortality from breast cancer since optimal access to care and early diagnosis and treatment are crucial for mortality control [38]. Besides, a costeffectiveness analysis of breast cancer control interventions in Peru [39] showed that the current program could be improved by implementing triennial or biennial screening strategies. Such a strategy would offer critical treatment to cases detected in the early stages and, consequently, to offer higher quality health coverage to the population.

\section{Limitations and strengths}

This study has several limitations: 1) the lack of a highquality national death registration. However, the calculation was made with correction for underreporting, informed by the Ministry of Health. 2) The absence of a National Cancer Registry that provides nationwide incidence data. Interpreting mortality without incidence data in each province, could lead to a bias of interpretation of results. The Lima Metropolitan Cancer Registry (collecting data from Lima, capital from Peru) and the Arequipa Population Cancer Registry are the only cancer registry active in Peru, although have not reported data in quite a long time. 3) Although the SEGI world standard population was used, it is not really comparable to the SEGI standardized mortality rates from other countries, as the normal SEGI population used 
18 age-groups, versus only 3 broad age groups $(0-29,30-$ 59 , and $\geq 60$ ) in this study. These very broad age groups can still hide substantial ageing of the population and therefore are not really comparable to rates of other countries. As a strength of our work, this is the first large scale study for Peru and its geographical areas that evaluated the changes in breast cancer mortality.

\section{Conclusion}

Our study showed a stable mortality trend of breast cancer in Peruvian women. Moreover, their rates still have lower compared to other Latin American countries. The highest mortality rates from breast cancer were observed in the coastal region, but a recent downward trend was observed since 2005. Also, increasing mortality trends were seen in the highland region. The disparities may be related to variable death certification validity, the access to early diagnosis, and treatment for breast cancer. Tailored public health interventions to reduce breast cancer mortality should be implemented in Peru.

\section{Abbreviations}

ASMR: Age-standardized mortality rate; ASMRs: Age-standardized mortality rates; BC: Breast cancer; LMICs: Low- and middle-income countries; NSI: National Statistics Institute; TNBC: Triple-negative breast cancer

\section{Acknowledgements}

Not applicable.

\section{Authors' contributions}

Conceived and designed the idea: JSTR, JYM. Had full access to all the data in the study and take responsibility for the integrity of the data and the accuracy of the data analysis: JSTR, JYM, GC. Contributed to the writing of the manuscript: JSTR, JFMH, GC, JYM, BV. Contributed to the statistical analysis: JSTR. Critical revision of the manuscript: JAP, AA, CL, KAM. Approval of the submitted and final version: JSTR, JFMH, GC, JYM, BV, JAP, AA, KAM, $\mathrm{CL}$.

\section{Funding}

No funding was obtained for this study.

\section{Availability of data and materials}

The datasets used and/or analysed during the current study are available from the corresponding author on reasonable request. You can also request the raw data through the following form: https://www.minsa.gob.pe/ portada/transparencia/solicitud/, placing your personal data and the information to be requested.

\section{Ethics approval and consent to participate}

Ethical approval and consent of the participant were not necessary since this study involved the use of a previously published secondary database.

\section{Consent for publication}

Not applicable.

\section{Competing interests}

The author(s) declare that they have no competing interests.

\section{Author details}

${ }^{1}$ Universidad Cientifica del Sur, Lima, Peru. ${ }^{2}$ Instituto de Investigación, Universidad Católica Los Ángeles de Chimbote, Chimbote, Peru. 'ªtin American Network for Cancer Research (LAN-CANCER), Lima, Peru. ${ }^{4}$ Cancer Center, Medical Center American British Cowdray, Mexico City, Mexico. ${ }^{5}$ Department of Clinical Sciences and Community Health, Università degli Studi di Milano, 20133 Milan, Italy. ${ }^{6}$ Universidad Privada San Juan Bautista,
Lima, Peru. 'Unidad de Investigación Básica y Traslacional, Oncosalud-AUNA, Lima, Peru. ${ }^{8}$ Division of Cancer Epidemiology and Genetics, National Cancer Institute, Bethesda, MD, USA.

Received: 2 June 2020 Accepted: 20 November 2020

Published online: 01 December 2020

\section{References}

1. Bray F, Ferlay J, Soerjomataram I, Siegel RL, Torre LA, Jemal A. Global cancer statistics 2018: GLOBOCAN estimates of incidence and mortality worldwide for 36 cancers in 185 countries. CA Cancer J Clin. 2018;68(6):394-424.

2. Fitzmaurice C, Dicker D, Pain A, Hamavid H, Moradi-Lakeh M, Maclntyre MF, et al. The global burden of cancer 2013. JAMA Oncol. 2015;1(4):505-27.

3. Justo N, Wilking N, Jönsson B, Luciani S, Cazap E. A review of breast cancer care and outcomes in Latin America. Oncologist. 2013;18(3):248-56.

4. Chatenoud L, Bertuccio P, Bosetti C, Malvezzi M, Levi F, Negri E, et al. Trends in mortality from major cancers in the Americas: 1980-2010. Ann Oncol. 2014:25(9):1843-53.

5. Carioli G, Bertuccio P, Malvezzi M, Rodriguez T, Levi F, Boffetta P, et al. Cancer mortality predictions for 2019 in Latin America. Int J Cancer. 2020; 147(3):619-32.

6. Carioli G, La Vecchia C, Bertuccio P, Rodriguez T, Levi F, Boffetta P, et al. Cancer mortality predictions for 2017 in Latin America. Ann Oncol. 2017; 28(9):2286-97.

7. Ruiz EF, Torres-Roman JS, Servan SA, Martinez-Herrera JF, Arce-Huamani MA, Carioli G, et al. Trends and geographic pattern of stomach cancer mortality in Peru. Cancer Epidemiol. 2019;58:193-8.

8. Torres-Roman JS, Gomez-Rubio V, Sanchez-Trujillo L, Delgado-Rosas E, Puche-Vergara F, Sanz-Anquela JM, et al. Geographic study of mortality due to mesothelioma in Peru and its evolution. Cancer Epidemiol. 2020;68: 101791

9. World Health Organization. International classification of disease and related health problems: 10th revision. Geneva: World Health Organization; 1992.

10. Instituto Nacional de Estadistica e Informatica. Boletín de Análisis Demográfico №37. Perú: Estimaciones y Proyecciones de Población por departamento, sexo y grupos quinquenales de edad, 1995-2025. Available from: http://proyectos.inei.gob.pe/web/biblioineipub/bancopub/Est/ Lib0846/index.htm.

11. Instituto Nacional de Estadística e Informática. Estado de la Población Peruana 2015. 2015 [cited 2017 January 20]. Available from: https:/www.inei.gob.pe/ media/MenuRecursivo/publicaciones digitales/Est/Lib1251/Libro.pdf.

12. Torres-Roman JS, Urrunaga-Pastor D, Avilez JL, Helguero-Santin LM, Malaga G. Geographic differences in overweight and obesity prevalence in Peruvian children, 2010-2015. BMC Public Health. 2018;18(1):353.

13. Ministerio de Salud. Oficina General de Estadística e Informática. Mortalidad General en el Perú 2007-2011 2013 [Available from: http://bvs.minsa.gob.pe/ local/minsa/2722.pdf.

14. World Health Organization. Age Standardization of Rates: A new Who Standard. 2011. Available from: http//www.who.int/healthinfo/paper31.pdf?ua=1.

15. National Cancer Institute. Joinpoint regression program. [Accesed 4 Apr 2020] .Available in: https://surveillance.cancer.gov/help/joinpoint.

16. Kim HJ, Fay MP, Feuer EJ, Midthune DN. Permutation tests for joinpoint regression with applications to cancer rates. Stat Med. 2000;19(3):335-51.

17. Kim HJ, Fay MP, Yu B, Barrett MJ, Feuer EJ. Comparability of segmented line regression models. Biometrics. 2004;60(4):1005-14.

18. Anselin L, Syabri I, Kho Y. GeoDa: an introduction to spatial data analysis. Geogr Anal. 2006;38(1):5-22.

19. Miki J, Rampatige R, Richards N, Adair T, Cortez-Escalante J, Vargas-Herrera J. Saving lives through certifying deaths: assessing the impact of two interventions to improve cause of death data in Perú. BMC Public Health. 2018;18(1):1329.

20. Carioli G, Malvezzi M, Rodriguez T, Bertuccio P, Negri E, La Vecchia C. Trends and predictions to 2020 in breast cancer mortality: Americas and Australasia. Breast. 2018:37:163-9.

21. Pinto JA, Pinillos L, Villarreal-Garza C, Morante Z, Villarán MV, Mejía G, et al. Barriers in Latin America for the management of locally advanced breast cancer. Ecancermedicalscience. 2019;13.

22. Instituto Nacional de Estadistica e Informatica. Población afiliada a algun seguro de salud. Lima; 2018. [In Spanish] [cited 2020 Mar 1]. Available from: https://www. inei.gob.pe/media/MenuRecursivo/publicaciones_digitales/Est/Lib1587/libro01.pdf. 
23. Torres-Roman JS, Arce-Huamani MÁ, Ruiz EF, Mejía CR. Actitudes frente a la autoexploración de mama en dos facultades de ciencias de la salud de Ica, Perú: un estudio piloto. Salud Publica Mex. 2017;59:117-8.

24. Hernández-Vásquez A, Chacón-Torrico H. Use of mammography in Peruvian women: an analysis of the 2018 Demographic and health survey. Medwave. 2019;19(9):e7701.

25. Piñeros M, Ramos W, Antoni S, Abriata G, Medina LE, Miranda JJ, et al. Cancer patterns, trends, and transitions in Peru: a regional perspective. Lancet Oncol. 2017;18(10):e573-e86.

26. Perú, Ministerio de Salud. Análisis de la Situación del Cáncer en el Perú, 2013. Lima: Dirección General de Epidemiología, MINSA; 2013. Available from: http://www.dge.gob.pe/portal/docs/asis_cancer.pdf.

27. Siegel R, Naishadham D, Jemal A. Cancer statistics for hispanics/latinos, 2012. CA Cancer J Clin. 2012;62(5):283-98.

28. Brooks JD, John EM, Mellemkjær L, Reiner AS, Malone KE, Lynch CF, et al. Body mass index and risk of second primary breast cancer: the WECARE study. Breast Cancer Res Treat. 2012;131(2):571-80.

29. Ferrari P, Licaj I, Muller DC, Andersen PK, Johansson M, Boeing H, et al. Lifetime alcohol use and overall and cause-specific mortality in the European prospective investigation into Cancer and nutrition (EPIC) study. BMJ Open. 2014;4(7):e005245.

30. Paluch-Shimon S, Cardoso F, Sessa C, Balmana J, Cardoso M, Gilbert F, et al. Prevention and screening in BRCA mutation carriers and other breast/ ovarian hereditary cancer syndromes: ESMO clinical practice guidelines for cancer prevention and screening. Ann Oncol. 2016;27(5):v103-v10.

31. Greenup R, Buchanan A, Lorizio W, Rhoads K, Chan S, Leedom T, et al. Prevalence of BRCA mutations among women with triple-negative breast cancer (TNBC) in a genetic counseling cohort. Ann Surg Oncol. 2013;20(10):3254-8.

32. Kumar R, Geuna E, Michalarea V, Guardascione M, Naumann U, Lorente D, et al. The neutrophil-lymphocyte ratio and its utilisation for the management of cancer patients in early clinical trials. Br J Cancer. 2015;112(7):1157-65.

33. Vallejos CS, Gómez HL, Cruz WR, Pinto JA, Dyer RR, Velarde R, et al. Breast cancer classification according to immunohistochemistry markers: subtypes and association with clinicopathologic variables in a peruvian hospital database. Clin Breast Cancer. 2010;10(4):294-300.

34. De-la-Cruz-Ku G, Luyo M, Morante Z, Enriquez D, Möller MG, ChambergoMichilot D, et al. Triple-negative breast cancer in Peru: 2000 patients and 15 years of experience. PLoS One. 2020;15(8):e0237811.

35. Tamayo LI, Vidaurre T, Vásquez JN, Casavilca S, Palomino JIA, Calderon M, et al. Breast cancer subtype and survival among indigenous American women in Peru. PLoS One. 2018;13(9):e0201287.

36. Vidaurre T, Santos C, Gómez H, Sarria G, Amorin E, López M, et al. The implementation of the plan Esperanza and response to the imPACT review. Lancet Oncol. 2017:18(10):e595-606.

37. Bain C, Constant TH, Contreras I, Vega AMB, Jeronimo J, Tsu V. Model for early detection of breast Cancer in low-resource areas: the experience in Peru. J Glob Oncol. 2018;4:1-7.

38. Goodson WH, Hunt TK, Plotnik JN, Moore DH. Optimization of clinical breast examination. Am J Med. 2010;123(4):329-34.

39. Zelle SG, Vidaurre T, Abugattas JE, Manrique JE, Sarria G, Jeronimo J, et al. Cost-effectiveness analysis of breast cancer control interventions in Peru. PLoS One. 2013;8(12):e82575.

\section{Publisher's Note}

Springer Nature remains neutral with regard to jurisdictional claims in published maps and institutional affiliations.

Ready to submit your research? Choose BMC and benefit from:

- fast, convenient online submission

- thorough peer review by experienced researchers in your field

- rapid publication on acceptance

- support for research data, including large and complex data types

- gold Open Access which fosters wider collaboration and increased citations

- maximum visibility for your research: over $100 \mathrm{M}$ website views per year

At BMC, research is always in progress.

Learn more biomedcentral.com/submissions 